\title{
A national survey of the citizenship information needs of the general public
}

\author{
Rita Marcella and Graeme Baxter \\ School of Information and Media \\ The Robert Gordon University, Aberdeen
}

\begin{abstract}
This paper reports the results of a survey of information needs and information seeking behaviour of a national sample of the UK population. The survey was the first stage of the Citizenship Information project, funded by the British Library Research and Innovation Centre. In total, 1294 responses were received giving a valid and demographically representative response rate of $45.7 \%$. Major findings include: that the majority of respondents had sought information in the past (59.4\%) and that an even greater number predicted a future need for information (78.4\%). Over three quarters of respondents said that they would use public libraries and between half and three quarters would approach Citizens Advice Bureaux, post offices, government departments or family and friends. Face to face communications and reading a book were the most popular means of accessing information, but a wide variety of other preferred options were cited. Only a small proportion expressed a preference for using a computer to seek information, and there was a clear emphasis on public libraries as an appropriate location for accessing electronic information. A highly significant majority (79.2\%) believed that access to information was very important for exercising their rights as a citizen.
\end{abstract}

\section{Introduction and background}

This paper reports the results of the first stage of the Citizenship Information research project, funded by the British Library Research and Innovation Centre. The main aims of this project are to: investigate the extent to which members of the UK public have expressed or unexpressed needs for citizenship information; explore their preferred routes to the acquisition of such information; and explore the suitability and approachability of the public library, among other agencies, for the user seeking citizenship information. Stage one of the project consisted of a questionnaire-based survey of a sample of the UK population, designed to gather preliminary data on their use of and need for citizenship information.

In the design and execution of the project, the authors drew upon a range of existing research and published literature. This has included the work of Marshall ${ }^{1}$, the National Consumer Council $^{2}$ and the Policy Studies Institute ${ }^{3}$ on the role of information in citizenship and the distinction between the citizen consumer and the active or participant citizen. There were also links with some observers' definitions of community information, including those of the 
Library Association ${ }^{4}$ and Donohue ${ }^{5}$. Prior research on information needs, including that of Bruce et $a l^{6}$, Tinker $a t a l^{7}$, and most importantly Warner et $a l^{8}$ and the University of Sheffield ${ }^{9}$, has also been relevant. Professional and representative bodies, such as the Library Association ${ }^{10}$ and the Library and Information Commission ${ }^{11}$ have argued the importance of public libraries providing citizenship information; while commentators such as Usherwood $^{12}$ and Swash and Marsland ${ }^{13}$ have predicted a rise in public expectation of public libraries in terms of citizenship information provision.

The Citizenship Information project has been ongoing at a time of great change in terms of information policy formulation and development in the UK. A non-statutory Code of Practice on Access to Government Information ${ }^{14}$ was introduced in 1994; while the Freedom of Information White Paper ${ }^{15}$ was published in 1997 with a view to establishing a general statutory right of access to official records and information. The 1998 Crown Copyright Green Paper ${ }^{16}$ suggested the possible abolishment of Crown Copyright and the placing of all government material in the public domain.

The use of Information and Communication Technologies (ICTs) to enable the exchange of citizenship information has also been the focus of much attention. The government.direct Green Paper $^{17}$, for example, was issued as a prospectus for the electronic delivery of government services to citizens and the business community; the Central Computer and Telecommunications Agency's online Government Information Service ${ }^{18}$ attempts to provide a coordinated single point for information produced by government departments and agencies; while the UK Citizens Online Democracy (UKCOD) ${ }^{19}$ service has conducted some interesting experiments in electronic democracy. Plans are also in place to establish an electronic network linking public libraries - The People's Network ${ }^{20}$ - which the government believes will play a central role in delivering its wider objectives for the role of technology in society. The Parliamentary Office of Science and Technology has issued an Electronic Government report ${ }^{21}$ which discusses the benefits and issues arising from these and other initiatives. 


\section{Methodology}

The stage one questionnaire was disseminated across all 13 government office regions of the UK. Overall, 1294 questionnaires were completed and returned, giving a 45.7\% response rate. Each of the regions achieved a response rate between $35.5 \%$ and $54.5 \%$, apart from Northern Ireland at $75 \%$ and Wales at only $14.7 \%$.

Questionnaires were handed to users in public libraries, Citizens Advice Bureaux and other generalist information and advice agencies. A much better response was achieved in the public libraries (69.4\%) than in the $\mathrm{CABx}(40.5 \%)$ and other advice and information agencies $(8.3 \%)$. With over $75 \%$ of the completed questionnaires having been distributed in public libraries, survey results may be somewhat biased towards the opinions of public library users: the Library and Information Commission's report New Library: The People's Network ${ }^{22}$ indicated that libraries are used by only $58 \%$ of the UK public. The survey response does not indicate, however, any groups excluded or poorly represented in the sample.

Table 1 shows the gender and age representation of the sample.

\begin{tabular}{|l|c|c|c|c|}
\hline \multicolumn{5}{|l|}{ Table 1: Gender and age of respondents } \\
\hline & \multicolumn{5}{|c|}{ Gender } \\
\hline & Male & Female & $\begin{array}{c}\text { Not } \\
\text { specified }\end{array}$ & Totals \\
\hline Age Group & 10 & 21 & - & $31(2.4 \%)$ \\
\hline $15-19$ & 37 & 61 & 1 & $99(7.7 \%)$ \\
\hline $20-29$ & 126 & 120 & 1 & $247(19.1 \%)$ \\
\hline $30-44$ & 177 & 190 & 1 & $368(28.4 \%)$ \\
\hline $45-54$ & 90 & 111 & - & $201(15.5 \%)$ \\
\hline $55-64$ & 82 & 76 & 1 & $159(12.3 \%)$ \\
\hline $65-74$ & 71 & 54 & 3 & $128(9.9 \%)$ \\
\hline 75 or over & 33 & 16 & 3 & $52(4.0 \%)$ \\
\hline Age not specified & 4 & 4 & 1 & $9(0.7 \%)$ \\
\hline & $\mathbf{6 3 0}$ & $\mathbf{6 5 3}$ & $\mathbf{1 1}$ & $\mathbf{1 2 9 4}(\mathbf{1 0 0 \%})$ \\
\hline & $\mathbf{( 4 8 . 7 \% )}$ & $\mathbf{( 5 0 . 5 \% )}$ & $(\mathbf{0 . 9 \%})$ & \\
\hline
\end{tabular}

In total, $100(7.7 \%)$ of the respondents belonged to an ethnic minority group. $55.5 \%$ of the respondents were economically active (i.e. working or looking for work). With regard to the economically inactive respondents in the survey, $14.1 \%$ were students. Respondents to the survey come to a greater extent proportionally from the professional and managerial categories than for the UK as a whole. 
There were some interesting differences in status, between the respondents in the three types of organisation involved in the survey: the proportion of jobseekers in the CABx (22.5\%) and the other advice agencies (21.2\%) was effectively twice that in the public libraries (10.9\%), which perhaps reflects the concerns this group would have about obtaining information and advice; while the public library student percentage (16.0\%) was virtually double those in the $\mathrm{CABx}(8.7 \%)$ and the other agencies $(6.1 \%)$.

123 respondents $(9.5 \%)$ indicated they were disabled in some way. The proportion of disabled respondents in the $\mathrm{CABx}(15.0 \%)$ and the other advice agencies (27.2\%) was significantly greater than in the public libraries $(6.9 \%)$.

\section{Survey results}

Respondents were asked to give an example of an occasion on which they had been required to look for information to help them make a decision, solve a problem, or understand something a little better; 769 respondents (59.4\%) gave an example. They indicated a wide range of situations in which a need had arisen. Information for educational purposes was cited most frequently, by over a quarter of the respondents, followed by leisure and recreation information (16.9\%). Health care information, information on welfare benefits eligibility, and legal information were also prominent. When subsequently presented with a list of 23 subjects, $1100(85 \%)$ had wanted to find out more about at least one of the categories. The top 6 responses remained: information on education, leisure, health care, welfare benefits, legal issues and employment.

There were some significant demographic differences: for example, $42.1 \%$ of the female respondents had indicated a past need for educational information, compared with $31.7 \%$ of male respondents: male respondents, meanwhile, had had more interest in technology and communications $(+7.0)$ and political information $(+6.2)$. For certain types of information (e.g. local government, health care, taxation, financial matters, legal issues) the percentages for those aged 19 or under were decidedly lower than the other age groups. Welfare benefits information had been needed in the past by $36.7 \%$ of those respondents currently seeking work and by $29.1 \%$ of those who were running a home, but only by $17.5 \%$ of the retired and $16.5 \%$ of the students. Geographic variations were also prevalent if inexplicable. For example, only $9.2 \%$ of East Midlands respondents cited a past need for housing information, compared with $31.1 \%$ of those in the South East. Ethnic minority respondents demonstrated a greater need for immigration and nationality information and information on equal rights 
and discrimination. Disabled respondents had more frequently sought information on welfare benefits and health care. Finally, there appeared to be a significant relationship between past need for information on certain topics, and the type of organisation in which the questionnaires were distributed. For example, a greater proportion of respondents in $\mathrm{CABx}$ and other advice agencies had required welfare benefit and housing information, than had public library users.

When asked why information had been sought, almost half of the survey sample (48.8\%) identified educational and study reasons, and significant numbers also cited work-related reasons, family and personal reasons, and general interest. There was a fairly low incidence of information seeking for political decision making and for religious reasons.

Respondents were asked where they had gone to obtain information. The majority (66.7\%) had visited a public library, with $\mathrm{CABx}$ forming the only other significant source (17.7\%). However, not unexpectedly, a clear relationship emerged between the organisations cited and the type of organisation in which the questionnaires had been distributed. $88 \%$ of the respondents in public libraries cited public libraries as their source of information; $72.8 \%$ of CABx respondents cited Bureaux as their resource; while $84.3 \%$ of the users in the other advice agencies indicated that these agencies had been their preferred option.

Some interesting trends emerged when examining where respondents had gone to obtain particular types of information. Of the five most sought topics, public libraries were the most popular source for: educational information (84.4\%), leisure and recreation information (95.5\%) and information on health care (82.3\%). However, for legal information, only $37.5 \%$ had gone to a public library while $50 \%$ had gone to a $\mathrm{CAB}$ or another advice agency; and for information on welfare benefits only $5 \%$ had gone to public libraries compared with $75 \%$ having gone to $\mathrm{CABx}$ and other agencies.

Respondents were also asked how satisfied they were with the information they obtained. Greatest dissatisfaction was registered by users of legal and welfare benefits information and by those that had sought information from government departments.

$196(25.5 \%)$ respondents had encountered difficulties in the past in obtaining information. When asked to provide details, the majority indicated the types of information sought had proved difficult to acquire, with information on legal issues, education, welfare benefits, health care and employment being the most prominent. A number of respondents to this 
question indicated why the information had been difficult to obtain. The most common reason was that relevant resources were inadequate or were unavailable. Some respondents had encountered difficulties with using various elements of information systems, such as catalogues, classification schemes, and electronic databases; others felt that official secrecy had prevented their accessing material or had found information full of jargon.

Using the same list of 23 subjects discussed above, respondents were asked if they felt they might want to find out more about any of these topics in the future. 1014 (78.4\%) of the respondents predicted a future need for information. The top six subjects required in the past (leisure and recreation, education, employment, transport and travel, legal issues, and health care) were still regarded as the six types of information most likely to be required in the future, although in a slightly different order of preference. While there was a slight increase in the predicted need for legal information and health care information, less interest was anticipated in information on employment, transport, leisure and most significantly education. There was a significant increased perception of information need about the European Union in the future.

Women again had less interest in technology and politics, but a greater interest in family/personal information, health care, employment and education. For those aged 44 and under, predicted need was greater than past need for most subjects on the list; while for those aged 45 and over, predicted future use of the majority of subjects was less than past use. Students, jobseekers, and those respondents running a home displayed an increased future interest, compared to past need, in the majority of the topics; while predicted interest from retired respondents was lower in the majority of subjects. There were also a number of geographic variances, the causes of which were again not immediately obvious: for example, future interest in equal rights ranged from $6.1 \%$ in the East Midlands to 24.7\% in the North West. Respondents from ethnic minority groups, when compared with white respondents, again displayed a preference for information on immigration and equal rights. Disabled respondents showed a greater interest in welfare benefits and equal rights, but less of an interest in employment and politics.

The four most popular past reasons for seeking information (educational, work-related, family, and satisfying a general interest) are also regarded as the most likely reasons for requiring information in the future. There was, however, a significant reduction in predicted educational reasons; it might be hypothesised that this relates to difficulties in predicting 
future areas of educational deficiency. Political decision making and religious reasons were again regarded as the least likely motives for information seeking.

Respondents were given a list of organisations and people and asked to indicate whether they would approach them for information. In total, 1209 (93.4\%) of the respondents indicated they would approach at least one of the sources to obtain information.

\begin{tabular}{|l|c|c|}
\hline \multicolumn{3}{|l|}{ Table 2: Preferred sources of information } \\
\hline Organisations / People & No. & $\%$ \\
\hline 1. Public libraries & 1001 & 77.3 \\
\hline 2. Family and friends & 798 & 61.7 \\
\hline $\begin{array}{l}\text { 3. Offices of Govt. depts. and agencies (e.g. } \\
\text { Inland Revenue, Benefits Agency) }\end{array}$ & 697 & 53.9 \\
\hline 4. Post Offices & 687 & 53.1 \\
\hline 5. Citizens Advice Bureaux & 652 & 50.3 \\
\hline $\begin{array}{l}\text { 6. Professional people (e.g. doctors and } \\
\text { social workers) }\end{array}$ & 634 & 49.0 \\
\hline 7. Local council offices & 551 & 42.5 \\
\hline 8. Academic libraries & 509 & 39.4 \\
\hline 9. Other information and advice centres & 406 & 31.4 \\
\hline 10. MPs & 331 & 25.6 \\
\hline 11. Professional / Trade Associations & 293 & 22.6 \\
\hline 12. Chambers of Commerce & 121 & 9.4 \\
\hline
\end{tabular}

This is felt to be a significant area in terms of overall consideration of sources of access to information used by the public. Over three quarters of respondents would use public libraries. Between half and three quarters of the respondents would approach Citizens Advice Bureaux, post offices, Government departments and agencies, or their family and friends. Additional preferred sources of information included: the Internet; leisure centres; local councillors; interest groups; banks; community centres; trade and funding agencies; PTAs; religious organisations; schools, telephone help lines; tourist information centres; and voluntary agencies.

Women displayed a significantly greater preference for using five sources of information: family and friends, professional people, advice agencies, post offices and $\mathrm{CABx}$. For post offices, public libraries, academic libraries, advice agencies, Chambers of Commerce, professional people, and family and friends, the trend was for interest in using these sources to wane as respondents grew older. Use of Government departments ranged from $63.2 \%$ in the South East to $40.4 \%$ in Yorkshire and the Humber; while use of Chambers of Commerce ranged from $18.8 \%$ in the North West to $4.9 \%$ in Scotland. In all regions public libraries were the most frequently cited resource, from $68.8 \%$ of respondents in Yorkshire and the 
Humber to $93.2 \%$ in Wales. Respondents in rural areas, compared with those in other areas, displayed a significantly greater interest in obtaining information from local council offices, professional people, post offices and public libraries.

Ethnic minority groups displayed a significant preference for visiting advice agencies, academic libraries, post offices and Chambers of Commerce; although public libraries (77\%), and family and friends (65\%) remained the two most favoured sources. The resource most frequently cited by disabled respondents was $\mathrm{CABx}$ (58.5\%), and when compared with those without a disability, a significant preference was also shown for contact with MPs . Disabled respondents felt less inclined to obtain information from public libraries, academic libraries, family and friends and post offices.

Significant differences in preferred sources of information were also identified when examining the type of organisation in which the questionnaires were disseminated. For the users of $\mathrm{CABx}$ and advice agencies, $\mathrm{CABx}$ were their preferred source $(78.7 \%$ and $56.1 \%$ of respondents, respectively), followed by family and friends. While public libraries were third on the list of $\mathrm{CABx}$ users' preferences, they were actually sixth on the advice agency users' list, behind post offices, Government departments and professional people.

The survey sample was asked in which language respondents prefer to obtain information. Excluding the Welsh and Irish languages, only 1.4\% indicated a preferred minority language, compared with $7.7 \%$ of respondents that came from an ethnic minority. 
From a list of methods of obtaining information, respondents were asked to indicate their favourite three methods in order of preference.

\begin{tabular}{|l|c|}
\hline $\begin{array}{l}\text { Table 3: preferred methods of obtaining information - } \\
\text { ranked by weighted scores (where } 3 \text { points were awarded for a 1st } \\
\text { choice, } 2 \text { points for a } \text { 2nd choice, and 1 point for a 3rd choice) }\end{array}$ \\
\hline Method & Points \\
\hline 1. Talking face to face with someone & 1023 \\
\hline 2. Reading a book & 848 \\
\hline $\begin{array}{l}\text { 3. Looking through a collection without } \\
\text { help from the staff }\end{array}$ & 827 \\
\hline 4. Reading a newspaper & 679 \\
\hline 5. Talking by telephone to someone & 518 \\
\hline 6. Listening to the radio & 426 \\
\hline 7. Watching television & 411 \\
\hline 8. Reading a leaflet / pamphlet & 312 \\
\hline 9. Using a computer & 275 \\
\hline 10. Reading a magazine & 232 \\
\hline 11. Writing a letter & 171 \\
\hline
\end{tabular}

These data suggest that no single mechanism for enabling access to information should be seen as the ultimate solution to the information needs of the citizen. Rather a complementary range of solutions must be offered to the citizen.

There were a number of differences between age groups: use of a computer was cited as a preferred method by $40.6 \%$ of those aged 19 and under, and by $22.1 \%$ of those aged $20-29$, but by just $10.6 \%$ of those aged 30 or over. The use of computers was cited by $33 \%$ of students, but just $9.7 \%$ of those running a home and $3.4 \%$ of retired respondents. Regional variations were prevalent, but once again no clear trends were evident. Acquiring information through face-to-face communication, for example, was preferred by $60.2 \%$ of Scottish respondents, but only $30.6 \%$ of those in London. Ethnic minority respondents indicated a preference for obtaining information by using a computer and watching television. Disabled respondents, meanwhile, displayed a greater preference for listening to the radio and face to face communication.

Significant variances were also found when comparing preferred methods with the type of organisation from which the respondent obtained the survey form. For example, reading a book was preferred by $48.4 \%$ of public library users compared to $12.1 \%$ of the users of $\mathrm{CABx}$ and advice agencies, while reading a magazine was cited by $16 \%$ of library users compared with just $7.4 \%$ of Bureau and agency users. Face to face communication, on the 
other hand, was preferred by $68.8 \%$ of Bureau and agency users compared with $42.2 \%$ of library users; while telephone contact was cited by $40.3 \%$ of CABx and agency users, but only $24.7 \%$ of library users.

Respondents were asked how often they would use computers to look for information, if public access to computers was made more widely available. In all, 969 (74.9\%) of the respondents indicated they would use computers on at least an occasional basis in at least one of the places listed.

\begin{tabular}{|c|c|c|}
\hline \multicolumn{3}{|c|}{$\begin{array}{l}\text { Table 4: Use of public access computers on at } \\
\text { least an occasional basis }\end{array}$} \\
\hline Location & No. & $\%$ \\
\hline Computers in public libraries & 940 & 72.6 \\
\hline Computers in post offices & 488 & 37.8 \\
\hline $\begin{array}{l}\text { Computers in shopping } \\
\text { centres }\end{array}$ & 454 & 35.1 \\
\hline Computers in town halls & 378 & 29.2 \\
\hline
\end{tabular}

There was a clear emphasis on public libraries as an appropriate location for computerised access to information for a significant majority of the general public.

In the final question, respondents were asked if they believed that access to accurate and unbiased information is important for exercising their rights as citizens. A highly significant majority $(79.2 \%)$ believe that access to high quality information is very important for exercising their rights as citizens.

It was significant that younger respondents and students felt less certain of the importance of information than the other age groups. Again there were inexplicable regional differences. Belief that information was very important ranged from $90.6 \%$ in the South East to $67 \%$ in Yorkshire and the Humber.

\section{Conclusions}

It is felt that the survey response (1294) was sufficiently representative of the UK population for generalisations to be drawn. The majority of respondents (59.4\%) had sought information, while just under a quarter (23.8\%) had experienced difficulties in accessing information in the past. Information need related to a range of categories reflecting the significant areas of citizens' experience. Educational reasons for information seeking were 
the most frequently cited both in the past and the predicted future. However, other reasons, such as work-related and a general interest, were significant.

Over three quarters (77.3\%) of respondents said they would use public libraries on at least an occasional basis. Between $50 \%$ and $75 \%$ of respondents would approach Citizens Advice Bureaux, Post Offices, Government departments and agencies, or their family and friends.

Face to face communications were preferred by the largest number of respondents: however, the traditional book retained its appeal with the second highest number of citations. Other preferred options included browsing in a collection and by telephone. The media, too, were popular, with newspapers being more frequently cited than TV or radio. Only a small proportion of respondents expressed a preference for using a computer to seek information.

These data suggest that no single mechanism for enabling access to information should be seen as the ultimate solution to the information needs of the citizen. Rather a complementary range of solutions must be offered to the citizen.

There was a clear emphasis on public libraries as an appropriate location for computerised access to information for a significant majority $(72.6 \%)$ of the general public. However, other public places, such as Post Offices, shopping centres and town halls, would attract a significant body and proportion of the general public.

A highly significant majority (79.2\%) of the respondents believe that access to accurate and unbiased information is very important for exercising their rights as citizens.

\section{References}

${ }^{1}$ Marshall, T.H. Citizenship and social class. Cambridge: Cambridge University Press, 1950

${ }^{2}$ National Consumer Council. The fourth right of citizenship: a review of local advice centres. London: National Consumer Council, 1977.

${ }^{3}$ Policy Studies Institute. Information and citizenship in the United Kingdom. Draft report prepared as part of the European Commission's Information and citizenship in Europe study. London: Policy Studies Institute, 1995.

${ }^{4}$ Library Association. Community information: what libraries can do. London: Library Association, 1980. 
${ }^{5}$ Donohoe, J. C. Community information services - a proposed definition. In: Martin, S.K., ed. Community information politics. Proceedings 39th ASIS annual meeting. Vol. 13. Washington: American Society for Information Science, 1976.

${ }^{6}$ Bruce, I., McKennel, A., and Walker, E. Blind and partially sighted adults in Britain: the RNIB survey. London: RNIB, 1991.

${ }^{7}$ Tinker, A., McCreadie, C., and Salvage, A. The information needs of elderly people: an exploratory study. London: Age Concern Institute of Gerontology, 1993.

${ }^{8}$ Warner, E.S., Murray, A.D., and Palmour, V.E. Information needs of urban residents. Washington, DC: US Department of Health, Education and Welfare, Office of Education, Bureau of Libraries and Learning Resources, 1973.

${ }^{9}$ Beal, C. Studying the public's information needs. Journal of Librarianship, 11(2), 1979, 130-151.

${ }^{10}$ Library Association. Library Manifesto. London: LA, 1997.

${ }^{11}$ Library and Information Commission. Review of the public library service in England and Wales for the Department of National Heritage: final report. London: Aslib, 1995.

${ }^{12}$ Usherwood, R. The public library as public knowledge. London: Library Association, 1989.

${ }^{13}$ Swash, G. and Marsland, G. Current trends in the use of the public library information centre. Library Management, 15 (6), 1994, 20-22.

${ }^{14}$ Great Britain: House of Commons. Code of practice on access to government information. London: HMSO, 1994.

${ }^{15}$ Great Britain: House of Commons. Your right to know: the Government's proposals for a Freedom of Information Act. London: The Stationery Office, 1997. (Cm 3818)

${ }^{16}$ Great Britain: House of Commons. Crown copyright in the information age: a consultation document on access to public sector information. London: The Stationery Office, 1998. (Cm 3819).

17 government.direct: a prospectus for the electronic delivery of government services. Available at: http://www.open.gov.uk/citu/gdirect/ [Accessed March 1997]

${ }^{18}$ Government Information Service home page. Available at http://www.open.gov.uk [Accessed June 1998]

${ }^{19}$ UKCOD home page. Available at: http://www.democracy.org/uk/ [Accessed February 1998]

${ }^{20}$ Library and Information Commission. New library: the people's network. London: LIC, 1997. Available at http://www.ukoln.ac.uk/services/lic/newlibrary/full.html 
${ }^{21}$ Parliamentary Office of Science and Technology. Electronic government: information technologies and the citizen. London: Parliamentary Office of Science and Technology, 1998.

${ }^{22}$ Library and Information Commission, op. cit. 